\title{
Annals of Theoretical Psychology
}

Volume 4 


\section{EDITORIAL BOARD}

D. Bakan, York University, Canada

J. S. Bruner, New School for Social Research

D. T. Campbell, Lehigh University

R. B. Cattell, University of Hawaii at Manoa

H. J. Eysenck, University of London, England

C. F. Graumann, Universität Heidelberg,

Federal Republic of Germany

R. L. Gregory, University of Bristol, England

M. Henle, New School for Social Research

F. Klix, Der Humboldt Universität Zu Berlin, German Democratic Republic

S. Koch, Boston University

K. B. Madsen, Royal Danish School of

Educational Studies, Denmark

D. Magnusson, University of Stockholm, Sweden

G. Mandler, University of California, San Diego

G. A. Miller, Princeton University

K. Pawlik, University of Hamburg,

Federal Republic of Germany

K. Pribram, Stanford University

G. Radnitzky, Universität Trier,

Federal Republic of Germany

R. Rieber, The City University of New York

D. N. Robinson, Georgetown University

J. R. Royce, University of Alberta, Canada

J. F. Rychlak, Loyola University, Chicago

J. Smedslund, University. of Oslo, Norway

P. Suppes, Stanford University

O. K. Tikhomirov, Moscow University, USSR

S. Toulmin, The University of Chicago

W. B. Weimer, Pennsylvania State University

B. B. Wolman, New York

A Continuation Order Plan is available for this series. A continuation order will bring delivery of each new volume immediately upon publication. Volumes are billed only upon actual shipment. For further information please contact the publisher. 


\section{Annals of Theoretical Psychology}

Volume 4

\section{Edited by}

\section{LEENDERT P. MOS}

Center for Advanced Study in Theoretical Psychology

University of Alberta

Edmonton, Alberta, Canada

Plenum Press • New York and London 
The Library of Congress has catalogued this title as follows:

Annals of theoretical psychology.-Vol. 1- -New York, N.Y.: Plenum Press. 1984-

v.: ill.; $23 \mathrm{~cm}$.

Annual.

ISSN 0747-5241 = Annals of theoretical psychology.

1. Psychology-Philosophy-Periodicals.

BF38.A53

$150^{\prime} .5-\mathrm{dc} 19$

84-644088

Library of Congress

[8501]

AACR2 MARC-S

\section{ISBN 978-1-4615-6455-3 ISBN 978-1-4615-6453-9 (eBook)}

DOI 10.1007/978-1-4615-6453-9

Softcover reprint of the hardcover 1st edition 1986

(C) 1986 Plenum Press, New York

A Division of Plenum Publishing Corporation

233 Spring Street, New York, N.Y. 10013

All rights reserved

No part of this book may be reproduced, stored in a retrieval system, or transmitted in any form or by any means, electronic, mechanical, photocopying, microfilming, recording, or otherwise, without written permission from the Publisher 


\section{Contents of Earlier Volumes}

\section{Volume 1}

1. Cognition: Its Origin and Future in Psychology

Dalbir Bindra

2. Schema and Inference: Models in Cognitive Social Psychology

Carl F. Graumann and Michael Sommer

With commentaries by Thomas K. Scrull, Robert S. Wyer, Jr., Arie W. Kruglanski, and Kenneth J. Gergen, and a reply by the authors

\section{Freud's Secret Cognitive Theories}

Mary Henle

With commentaries by Joseph F. Rychlak, Lisa Gaelick, and Robert S. Wyer, Jr., and a reply by the author

4. Limitations of the Dispositional Analysis of Behavior

Walter B. Weimer

With commentaries by Gunnar Andersson, Gerard Radnitzky, and William W. Rozeboom, and a reply by the author

5. The Place of Individual Differences in a Scientific Psychology

H. J. Eysenck

With commentaries by Jeffrey A. Gray, James A. Wakefield, Jr., and D. Cartwright, and a reply by the author

\section{Volume 2}

1. Sociobiology: Toward a Theory of Individual and Group Differences in Personality and Social Behavior

J. Philippe Rushton

With commentaries by Arthur R. Jensen, Robin J. H. Russell, J. Philippe Rushton, Pamela A. Wells, and Philip E. Vernon, and a reply by the author

2. Psychoanalysis as a Scientific Theory

Benjamin B. Wolman

With commentaries by David A. Freedman, Rudolf Ekstein, and Gordon F. Derner, and a reply by the author

3. The Nature and Challenge of Teleological Psychological Theory

Joseph F. Rychlak 
With commentaries by Walter B. Weimer, Daniel N. Robinson, and William J. Baker, and a reply by the author

4. The Hypotheses Quotient: A Quantitative Estimation of the Testability of a Theory K. B. Madsen

With commentaries by Lewis Wolfgang Brandt, Mark F. Ettin, and Dirk L. Schaeffer, and a reply by the author

5. What Is Necessarily True in Psychology?

Jan Smedslund

With commentaries by Herman Tennessen, Fred Vollmer, and K. V. Wilkes, and a reply by the author

6. Interaction and the Person $\times$ Situation Debate: $A$ Theoretical Perspective Michael E. Hyland

With commentaries by Philip K. Peake, Lawrence, A. Pervin, Joel O. Raynor, and William T. Powers, and a reply by the author

\section{Volume 3}

1. Psychological Metatheory: An Introduction to Volume 3

K. B. Madsen

2. The Place of Theory in a World of Facts

H. J. Eysenck

With commentaries by Edward Erwin, Stephen P. Stich, and Alexander Rosenberg, and a reply by the author

3. From Mindless Neuroscience and Brainless Psychology to Neuropsychology

Mario Bunge

With commentaries by M. C. Corballis and P. C. Dodwell, and a reply by the author

4. Is Psychoanalysis Therapeutic Technique or Scientific Research? A Metascientific Investigation

Carl Lesche

With commentaries by Bo Larsson, Lars B. Lofgren, and Gerard Radnitzky, and a reply by the author

5. Psychology and Philosophy of Science

C. Sanders and H. V. Rappard

With commentaries by Hubert C. J. Duijker and Willis F. Overton, and a reply by the authors

6. The Problem of Theoretical Pluralism in Psychology

Joseph R. Royce

With commentaries by Michael E. Hyland, Stig Lindholm, and Richard E. Kitchener, and a reply by the author 


\section{Contributors}

Marek Aftowicz-Bielecki, Institute of Philosophy, University of Warsaw, Warsaw, Poland

William P. Alston, Department of Philosophy, Syracuse University, Syracuse, New York

David Bakan, Department of Psychology, York University, Downsview, Ontario, Canada

James Robert Brown, Department of Philosophy, University of Toronto, Toronto, Ontario, Canada

Mario Bunge, Foundations and Philosophy of Science Unit, McGill University, Montreal, Quebec, Canada

L. Jonathan Cohen, The Queen's College, Oxford, United Kingdom

James Deese, Department of Psychology, University of Virginia, Charlottesville, Virginia

Morris N. Eagle, Department of Psychology, York University, Downsview, Ontario, Canada

Owen Egan, Linguistics Institute of Ireland, Dublin, Ireland

Rand B. Evans, Department of Psychology, Texas A \& M University, College Station, Texas 
Ingemund Gullvåg, Department of Philosophy, University of Trondheim, Trondheim, Norway

Harry T. Hunt, Department of Psychology, Brock University, St. Catharines, Ontario, Canada

Anders Lindseth, Department of Philosophy, University of Troms $\varnothing$, Troms $\varnothing$, Norway

John Macnamara, Department of Psychology, McGill University, Montreal, Quebec, Canada

Thomas M. Nelson, Department of Psychology, University of Alberta, Edmonton, Alberta, Canada

Zofia Rosinska, Institute of Philosophy, University of Warsaw, Warsaw, Poland

Joseph F. Rychlak, Department of Psychology, Loyola University of Chicago, Chicago, Illinois

Tod S. Sloan, Department of Psychology, University of Tulsa, Tulsa, Oklahoma

Robert S. Steele, Psychological Laboratory, Wesleyan University, Middletown, Connecticut

Stephen P. Stich, Department of Philosophy, University of California, San Diego, La Jolla, California

Paul Swartz, Department of Psychology, University of Alberta, Edmonton, Alberta, Canada

Herman Tennessen, Center for Advanced Study in Theoretical Psychology, University of Alberta, Edmonton, Alberta, Canada 
Arild Utaker, Department of Philosophy, University of .Bergen, Bergen, Norway

Fred Vollmer, Department of Personality Psychology, University of Bergen, Bergen, Norway 


\section{Preface}

This discipline has become more reflective in recent years. It has also become blatantly philosophical, which is itself cause for reflection. The philosophy of psychology has not been exactly a burgeoning field, and yet psychologists and philosophers of all persuasions are writing philosophical psychology. Perhaps all this activity merely reflects the uneasy bifurcation of psychology into biological and cognitive domains. After all, there were similar flurries in the 1920s and 1950s when the discipline assumed new directions. But, before, there were too many things to do; scientific knowing seemed so compelling and so singular in methodology. Today, the entire enterprise is much more uncertain, and not just psychology, but all human scientific inquiry. The fundamental questions remain much the same, of course; what has changed is that philosophers are explicitly addressing questions of psychology and psychologists are at least implicitly engaged in philosophy. The bounderies are no longer clear cut! Theoretical psychology is as much the doing of philosophy as it is of experimental research. Volume 4 of these Annals attests to this state of affairs. The psychologists' style reflects their philosophical understanding; the philosophers differ according to what they take to be psychological knowledge.

In the tradition of empirical semantics, the philosopher Herman Tennessen is skeptical about the possibility of articulating whole world views, including scientific world views, but his advice to try to do so is accepted as a challenge in all the subsequent contributions. Anders Lindseth, a philosopher in the hermeneutic tradition, and Fred Vollmer, a psychologist in the tradition of ordinary language analysis, address the fledgling domain of personality theory. In doing so they manage to raise most of the issues of philosophical psychology: the nature of explanation, reductionism, the role of evidence, causal determination, the validation of theoretical constructs, and measurement. Lindseth presses for a hermeneutic science and in the process contributes to sub- 
stantive psychoanalytic theory. Vollmer proposes a theory of mind on the basis of ordinary language use which puts into question Cartesian dualism and the role of nomological-deductive explanation. In these two papers, together with the commentaries and replies, the reader is treated to clashes of world views and, within each of these, a rich array of subtleties in theory and of metatheory. Harry Hunt's revival of the subjective within psychology clarifies the currently exclusive concern with information rather than meaning. His paper exemplifies Tennessen's claim that world views are rooted in an intuitive, "totalitarian," disposition: the subjective meaning core of all cognition. Hunt's efforts serve to fill out those by Lindseth and Vollmer, who would probably find his proposal quite congenial. Owen Egan's explication of the concept of belief as he finds it in his splendid review of the psychological literature draws criticism from all his commentators. His paper, the commentaries, and the reply demonstrate just how difficult it is to do theoretical work when both experimental research and conceptual schemes are brought to bear. Finally, James Deese's review of Daniel Robinson's recent book is a sympathetic treatment by a research psychologist who has actually let the issues of philosophical psychology inform his work.

Tennessen's contribution was submitted in 1982! Commentaries were available in the following year when he retired from the University of Alberta to his native Norway. He reworked the manuscript and wrote a reply at the University of Oslo in 1984. Lindseth's contribution came by way of Tennessen; the two met in Dubrovnik in 1982. Commentaries and Lindseth's reply were completed in the fall of 1984 . Vollmer's paper was first submitted in 1983 and a revised version, much reduced in length, was accepted the following year. Commentaries and Vollmer's reply were available in 1985. Egan's contribution was submitted in 1983, followed by John Macnamara's commentary six weeks later! The other two commentaries and Egan's reply were completed in 1985. Deese's review of Robinson's Philosophy of Psychology was written last summer following the former's visit to our Center, where he used a prepublication draft of the book in his lectures.

The University of Alberta continues to support my involvement in the preparation of these volumes. I am grateful to Mrs. Evelyn Murison for her secretarial and editorial assistance. My thanks also to Mr. James Voogd who ran down references and did an early reading of the manuscript noting numerous anomalies in the text (all of which, I hope, have been corrected).

I have dedicated this volume to Professor Herman Tennessen. He, together with Ludwig von Bertalanffy (1901-1972) and Joseph Royce, 
founded our Center in 1967. Even since his retirement he remains an active participant. A scholar of remarkable breadth, he has always engaged psychologists and philosophers in an effort best called philosophical psychology.

LEENDERT P. MOS 


\section{Contents}

Chapter 1. From the Testimonies of the Senses to the Paradoxes of World View 1

Herman Tennessen

Tennessen and the Problem of Conceptual Schemes 17 James Robert Brown

In Defense of Realism and Scientism 23

Mario Bunge

Talking Turkey about Sense Stuff 27

Thomas M. Nelson

How to View the Whirl of Testimonies and Make Sense of Paradox 39

Ingemund Gullvåg

From the Testimonies of the Senses to the Paradoxes of World View: Reply to Commentators 53

Herman Tennessen

Chapter 2. On the Possibility of Establishing a Metascientific Foundation for Psychoanalysis 59

Anders Lindseth 
Psychoanalysis and Hermeneutics 99

Arild Utaker

Psychoanalysis as a Practical Hermeneutical Science 109

Marek Aftowicz-Bielecki and Zofia Rosińska

The Construal of Psychoanalysis as a "Practical

Hermeneutic Science": An Avoidance of Critical Issues 117

Morris N. Eagle

Conventions and Interpretation 127

Robert S. Steele

Reality, Psychoanalysis, and Hermeneutical Sciences:

Reply to Commentators 133

Anders Lindseth

Chapter 3. Personality Psychology and the Hypothetical-Deductive Model of Explanation 157

Fred Vollmer

The Hypothetical-Deductive Model in Personality

Psychology 199

William P. Alston

Problems with Hypothetical-Deductive Explanation:

Methodological or Theoretical? 207

Joseph F. Rychlak

Breaking the Objectivist Stranglehold on Personality Psychology 227

Tod S. Sloan 
Personality Psychology and the Hypothetical-Deductive Model of Explanation: Reply to Commentators 233

Fred Vollmer

Chapter 4. A Cognitive Reinterpretation of Classical Introspectionism: The Relation between Introspection and Altered States of Consciousness and Their Mutual Relevance for a Cognitive Psychology of Metaphor and Felt Meaning 245

Harry T. Hunt

Titchener's Relativistic View of Observation and Psychological Processes 291

Rand B. Evans

True and False and Good and Bad in Connection with Cognition, Affection, and Volition 299

David Bakan

Professor Hunt, Meet Professor Whitehead 303

Paul Swartz

A Cognitive Reinterpretation of Classical Introspectionism: Reply to Commentators 307

Harry T. Hunt

Chapter 5. The Concept of Belief in Cognitive Theory 315

Owen Egan

Leaving Belief Behind 351

Stephen P. Stich 
But What Is Belief Itself? 357

John Macnamara

An Ambiguity in Egan's Concept of Belief 365

L. Jonathan Cohen

The Concept of Belief in Cognitive Theory: Reply to Commentators 369

Owen Egan

Book Review. The Right Stuff: A Review of D. N. Robinson's The Philosophy of Psychology. New York: Columbia University Press, 1985381

James Deese

Author Index 393

Subject Index 399 